\title{
Susan Hockfield
}

How does a female life scientist lead a campus full of male engineers? Susan Hockfield rises to the challenge with equal parts caution and confidence.

The names of the great men of science-Darwin, da Vinci, Copernicusare carved in stone on the grounds of the Massachusetts Institute of Technology (MIT) in Cambridge. More than 100 names grace the neoclassical buildings that surround the campus' Killian Court-and not a woman among them.

But inside, for the first time, a woman is in charge of this bastion of male physical scientists. In December, neuroscientist and former Yale provost Susan Hockfield became MIT's first female president. Hockfield is also the first biomedical researcher to hold the job.

"To think that MIT would choose a non-engineer, a life scientist, speaks to two things," says Lydia Villa-Komaroff, vice president of research at the neighboring Whitehead Institute, an MIT affiliate. "One is the evolution of the institution itself - and the other is [Hockfield's] reputation as an effective, fair and visionary leader."

In recent years, MIT has been marked by a greater emphasis on biomedical research and much public soul-searching about the paucity of women in its upper echelons. But Hockfield says she does not see herself as a trailblazer for women scientists. "There's always a first," she says.

If Hockfield is at all intimidated by the prospect of leading a school with ten Nobel prize winners and a reputation as the world's top technical university, she doesn't show it. A slight woman who favors business suits and light makeup, she strides into the job with good humor and gusto.

Although her official inauguration is in May 2005, Hockfield began her work at MIT in early December. She arrives at her office, with its view of the green expanse of Killian Court and the Charles River, at about 8 a.m. each day. Her full day usually leads to an evening event and beyond.

In her first few weeks, she has lunched with the female faculty, posed with her moving boxes for the graduate student newsletter and hosted a reception at her home for MIT's most recent Nobel Prize winner, physicist Frank Wilczek. Even before moving to Cambridge, she also attended a black-tie gala for new Boston Symphony Orchestra Music Director James Levine.

Hockfield says her life as a scientist has prepared her well for her new position. Even when she ran her lab, she sought ideas and input from her entire team, a process she says she finds enormously productive as an administrator. "I do my thinking better in a group than I do on my own. And that's the way science is done," she says. "We don't do science by living and working in isolation...You don't know which idea is going to spark an insight in your mind so you have to gather lots of ideas."

Hockfield won't even discuss her vision for MIT until after the inauguration. As she tells it, that won't be fully formed until she hears what her new constituency has to say. "She's not one to rush into things," says Cold Spring Harbor Laboratory (CSHL) President Bruce Stillman, who has known Hockfield for 20 years. "It's absolutely typical of Susan to go around talking to everyone. She's inclusive and very effective at synthesizing information."

Hockfield shares one important qualification with MIT's many engineers. As a child, she enjoyed taking machines apart to see how they worked. Although her teachers encouraged her to consider a career in medicine, she had her own ideas. "It wasn't disease I was interested in," she says. "I was interested in basic biology." After earning a $\mathrm{PhD}$ in anatomy at Georgetown University, she went on to CSHL, where she encountered electron microscopy.
"Boy, it was so great," she recalls. "What I found most compelling was the transformation through structure to function." She spent long nights in the lab analyzing data as she explored the role of the extracellular matrix in the developing human brain. In those early days of molecular biology, her team was one of the first to use monoclonal antibodies as a research tool. Her work eventually led her from CSHL to Yale in 1985.

Hockfield was so passionate about her research, she says she never envisioned herself straying too far from the lab. "I was fully planning on living my whole life as a scientist," she says. "I love being a scientist. It's very exciting, and a privilege, to see things that no one has ever seen before."

But when Hockfield was named a candidate for dean of Yale's Graduate School of Arts and Sciences in 1998, she was intrigued. She says she saw the offer as an opportunity to better serve Yale. At the time, the Graduate School was embroiled in a contentious battle over the unionization of graduate students. Hockfield has been praised for improving benefits for graduate students while opposing their efforts to unionize. But some union organizers say she was unsympathetic to their concerns about the dead-end job market for postdoctoral fellows.

"We don't do science
by living and working
in isolation ... You don't
know which idea is going
to spark an insight in
your mind so you have to
gather lots of ideas."

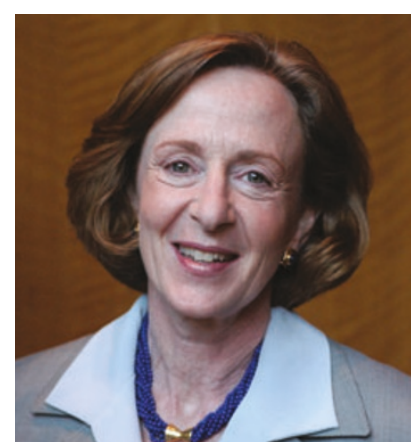

"I was a little disappointed with her response to the postdoc crisis: either it doesn't exist or you don't have to worry because you're coming from Yale," recalls Maris Zivarts, a Yale graduate student in molecular biology. "That put some people at ease, but for some people that was a kind of an unsatisfactory answer," Zivarts says.

Hockfield takes issue with the notion that she failed to advocate for postdocs and points to a set of policies she created to improve the postdocs' lot. Union spokeswoman Rachel Sulkes says whatever her stance, Hockfield was at least forthright. "She would tell you where she stood," Sulkes says. "A lot of people around here won't."

Along with her substantial duties as dean, Hockfield maintained a hand in the lab. She continued to do so even after she became Yale's provost, the university's highest post after president. But she only had to juggle the two jobs for less than two years before accepting the job at MIT.

On her first day at MIT in December, Hockfield had lunch with the department heads and invited the entire MIT community-including the eight-foot 'Tim the Beaver' mascot— to a festive afternoon reception. For most of the two hours, she held court in a student center, shaking hands with anyone willing to wait in a long line that snaked out the door and down the hall.

Among those waiting to meet her was Irwin Pless, emeritus professor of physics at the university. If Pless is any indication, Hockfield won't face much resistance from MIT's old guard. "I'm happy they chose a well-qualified professional and I'm very pleased that it's a woman," Pless said. "From what I hear about her, she will fit in well."

Tinker Ready, Cambridge 